\title{
CONSTANT DENDRITIC COVERAGE BY GANGLION CELLS WITH GROWTH OF THE GOLDFISH'S RETINA
}

\author{
Peter F. HitchCock* \\ Division of Biological Sciences, The University of Michigan, Ann Arbor, MI 48109. U.S.A.
}

(Received 3 April 1986; in revised form 28 May 1986)

\begin{abstract}
This study demonstrates that in the retina of the goldfish a type of ganglion cell, whose dendritic development has been well characterized [Hitchcock P. F. and Easter S. S. Jr (1986) J. Neurosci. 6, 1037-1050], is distributed across the retina in a nonrandom pattern, and the dendritic fields of this cell type overlap to completely cover, or "tile" the retina. Further, it is shown that the dendritic coverage of the retina by this cell type is established when the retina is small and is maintained as the retina grows.
\end{abstract} $\begin{aligned} & \text { Goldfish Retina Ganglion cells Retinal development Dendritic growth Horseradish per- } \\ & \text { oxidase }\end{aligned}$
.

\section{INTRODUCTION}

The goldfish's retina, like that of other teleosts (Müller, 1952; Lyall, 1957; Ali, 1964; Sandy and Blaxter, 1980; Kock and Reuter, 1978a; Kock, 1982a) grows throughout the life of the animal (Easter et al., 1977; Johns and Easter, 1977; Meyer 1978). This growth is a result of two phenomena; the addition of new neurons from a ring of neuroepithelium at the retinal margin (Johns, 1977; Meyer, 1978; Sharma and Ungar, 1980) and a balloon-like expansion of the existing retina, which results in an increase in retinal area and a decrease in cell density (Johns and Easter, 1977).

Prompted by these data, Hitchcock and Easter (1986) studied the dendritic development of a type of large ganglion cell (designated the Type 1.2 cell) in the goldfish's retina. It was discovered that the dendrites of this cell develop in a manner that is related to the growth of the retina. First, in an annular zone just central to the proliferative margin, these cells elaborate new dendrites. Second, the dendritic arbors of these cells enlarge as the retina expands. This enlargement was hypothesized to result from the passive towing of the dendrites by the expanding retina.

Wässle and his co-workers (Wässle and Rie-

*Present address: School of Medicine. Department of Ophthalmology, The University of Michigan, W. K. Kellogg Eye Center, Ann Arbor, MI 48105, U.S.A. mann, 1978; Wässle et al., 1981a, b, 1983) have shown that in the cat's retina, alpha and beta ganglion cells are distributed across the retina in a nonrandom pattern. In addition, they directly demonstrated that the dendritic fields of each class of cell (On- and Off- alpha and beta) overlap independently such that every retinal point is covered by the dendritic field of at least one cell. This complete coverage of the retina by the dendrites of a single class of cells [known as dendritic coverage, or "tiling" (Wässle et al., $1981 \mathrm{~b}$ )] is a feature of other retinal neurons as well (Brecha et al., 1984, see also Tauchi and Masland, 1984).

To determine whether those features of alpha and beta ganglion cells described above are common to the Type 1.2 cell in the goldfish, I have investigated whether this cell is nonrandomly distributed across the retina and whether the dendritic fields of adjacent cells overlap to cover the retina. In addition, to gain insight into the role that stretch may play during retinal growth and dendritic development, I have investigated whether the dendritic coverage of the retina by this ganglion cell type is maintained as the retina grows.

\section{MATERIALS AND METHODS}

Retinae from two fish $(3.9 \mathrm{~cm}$ standard length, $c a 1$ year old; $14.0 \mathrm{~cm}$ standard length, ca 4-5 year old) were analyzed for this study. A complete description of the histological meth- 
ods is contained in an earlier paper (Hitchcock and Easter, 1986). Briefly, the optic nerve was sectioned intraorbitally, and a pledget of Gelfoam soaked in a $30 \%$ solution of horseradish peroxidase (HRP) in $2 \%$ DMSO was placed in the orbit adjacent to the cut. Two or four days later (the larger fish survived longer), each fish was dark adapted for $1 \mathrm{~h}$ and deeply anesthetized in tricaine methanesulfonate. After each eye was removed, the retina was separated from the eyecup in a phosphate buffer, and wholemounted on a gelatinized slide, receptor side down. Following a $30 \mathrm{~min}$ fixation in $2 \%$ glutaraldehyde in a $0.2 \mathrm{M}$ phosphate buffer (pH 6.7), Adams's (1977) protocol was used to visualize the HRP. Each retina was then dehydrated in alcohols, cleared in xylene, and coverslipped. Using this technique, Hitchcock and Easter (1986) showed that in retinal regions where the ganglion cell labelling was judged to be most complete virtually all neuronal profiles were HRP positive. Inspection of isolated, HRP-filled ganglion cells revealed that this labelling technique stains very fine dendritic spines and appendages as well as the thin, distal branches on the dendritic arbors of all cell types [Hitchcock, unpublished observations; see also Hitchcock and Easter (1986), Figs 3 and 4]. It is assumed here that in the regions of the retinae analyzed all ganglion cells and their arbors are completely filled with HRP.

Type 1.2 cells were identified according to the criteria outlined by Hitchcock and Easter (1986). Relative to the other ganglion cells, the Type 1.2 cells have very large somata, two to three thick, slowly tapering primary dendrites, which form a very large dendritic field that is unistratified within the distal-most zone of the inner plexiform layer. The relative features that distinguish the Type 1.2 cell from the other ganglion cells remain constant as the retina grows, consequently there is no ambiguity in identifying this cell in retinae of small and large fish.

The retinal distribution of the Type 1.2 cells was plotted by scanning each retina at $\times 650$ magnification, and then marking the location of the soma of each on a camera-lucida drawing at $\times 12.5$ magnification. Dendritic fields were drawn by tracing the dendrites of each cell at $\times 1250$ magnification, and marking the locations of the tips of the dendrites on a low-power camera-lucida drawing. The tips of the most distal dendrites were then connected with a line to produce a convex polygon.

\section{RESULTS}

Figure 1(A) shows a camera-lucida drawing of a Type 1.2 cell from the central region of a retina similar in age and size to the one shown in Fig. 2(A). Figure 1(B) shows a camera-lucida drawing of a cell from the central region of the retina shown in Fig. 2(D). The cell from the small, young fish has a smaller soma. thinner dendrites,and a very much smaller dendritic field than the cell from the large, old fish. The number of dendrites each cell possesses, however, is similar. Hitchcock and Easter (1986) showed that with retinal growth the dendritic arbors of the Type 1.2 cells in central retina grow interstitially, without adding new dendrites.

Figures 2(A) and (D) are camera-lucida drawings of the wholemounted retina from each fish. Within each retina, each dot represents the location of the soma of a Type 1.2 cell. The outer dashed lines mark the boundary between the central retina, where the dendritic morphology of all Type 1.2 cells is similar, and peripheral retina, where these cells are adding new dendrites (Hitchcock and Easter, 1986; see Introduction). The inner dashed lines mark the boundary where the retinae were not suitable for viewing ganglion cells. A nearest neighbor analysis was performed for the Type 1.2 cells within the enclosed areas. The distance between each cell and its nearest neighbor was measured and compiled as a relative frequency histogram, which is illustrated in Fig. 2(B) and (E). The expected relative frequency distributions for a random pattern of cells at the same density were calculated from the equation derived by Wässle and Reimann (1978), and are shown by the smooth curves. A $\chi^{2}$ test between the observed and hypothetical distributions shows that in both retinae these cells are distributed nonrandomly $(P<0.0005)$. The distribution of the Type 1.2 cells was also analyzed using the statistical ratio: mean/standard deviation of the nearest neighbor distances (Eberhardt, 1967). Random patterns have a ratio of less than one. This procedure yielded values of 3.8 and 5.0 for the cells in the small and large retina, respectively, again demonstrating the nonrandom distribution of the Type 1.2 cells. Figure 2(C) and $(F)$ are camera-lucida drawings of the somata and dendritic fields of the fifteen adjacent Type 1.2 cells, which are enclosed by the thin, solid lines in the retinae in Fig. 2(A) and (D). Figure 2(C) illustrates that in the retina from the small fish the dendritic fields of adjacent Type 
1.2 cells overlap so that every retinal point is covered. This relationship holds for the cells from the large fish as well [Fig. 2(F)].

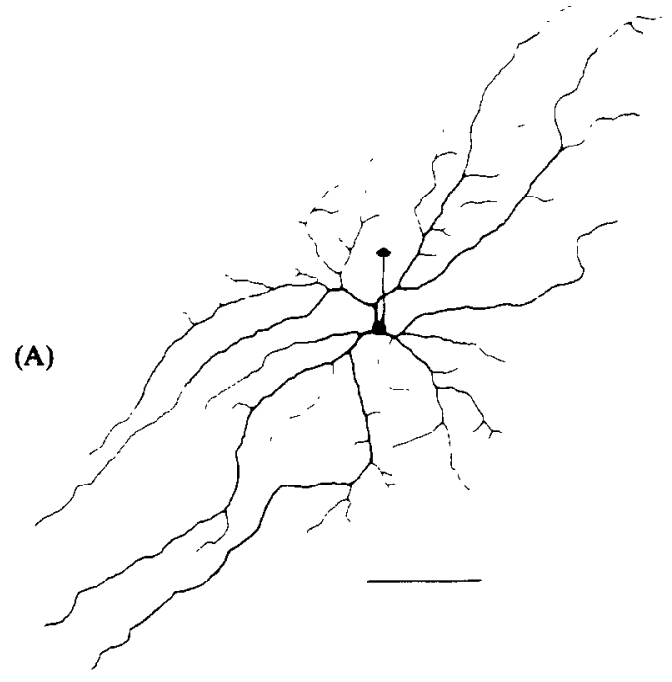

Because a cell in the central retina of a large, old fish was present when the retina and fish were much younger and smaller, one can learn the growth history for any cell, or group of cells by making comparisons between large and small retinae. Comparing Figs $(C)$ and $(F)$ illustrates that as the retina stretches and the somata move apart, the dendritic fields of the Type 1.2 cells increase in area, and the dendritic coverage of the retina by adjacent cells is maintained. [A]though the cells from the small retina would, over time, occupy a more central retinal position than those from the large retina it is assumed (Hitchcock and Easter, 1986) that any group of cells from central retina is representative of all others.] Consistent with this observation are the similar coverage factors [planimetric density $\times$ mean area of the dendritic field (Wässle et al., 1981a)] for the ganglion cells in these two retinae: 1.76 and 1.85 for the small and large retinae, respectively (Hitchcock and Easter, 1986).

(B)

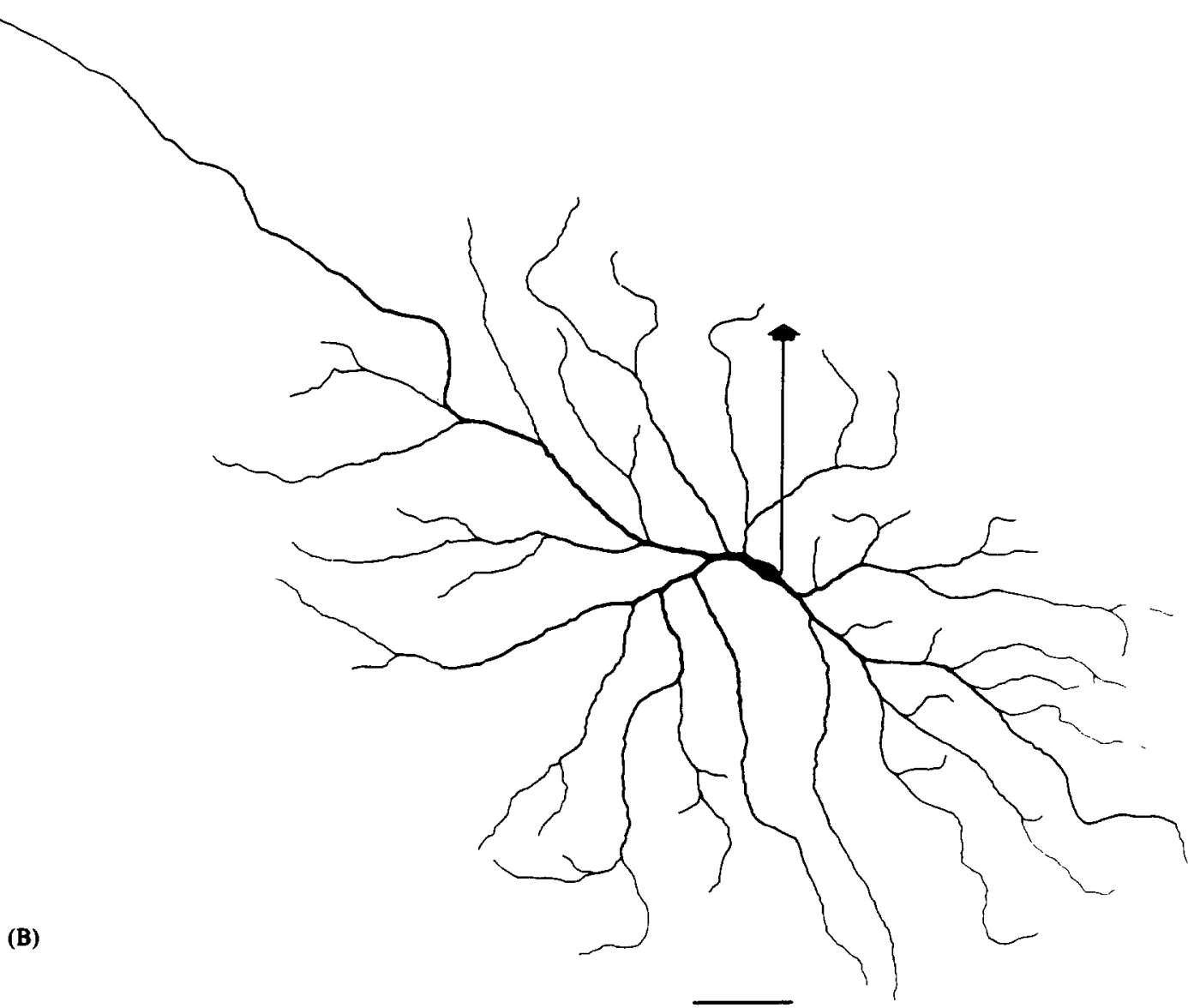

Fig. 1. Camera-lucida drawings of Type 1.2 cells from the central retina of a small, young goldfish (A), and a large, old goldfish (B). The arrowheads mark the axons. The optic dise is toward the top of the figures, the retinal margin is toward the bottom. Scale bars equal $100 \mu \mathrm{m}$. 


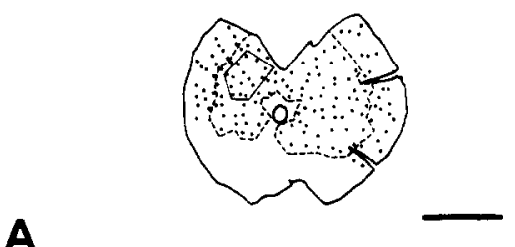

A

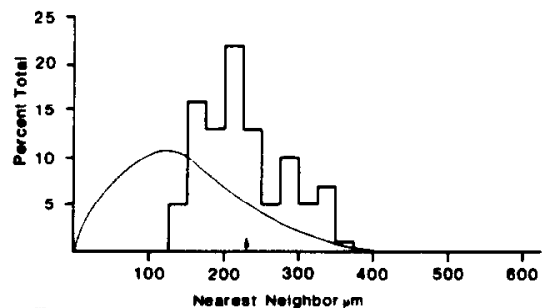

B

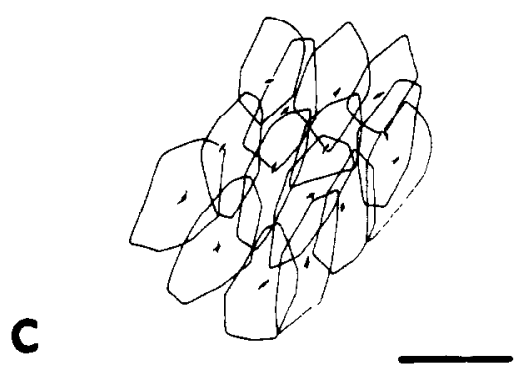

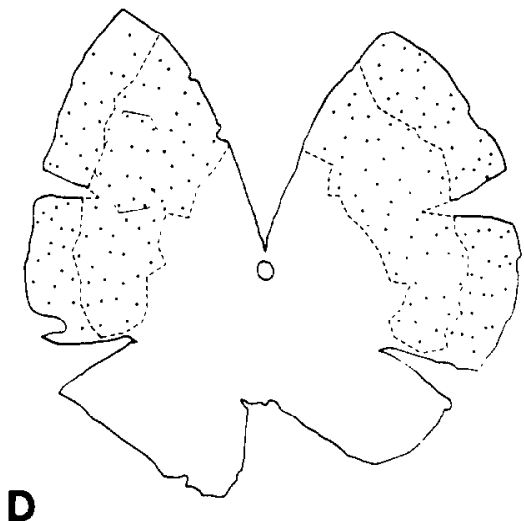

D
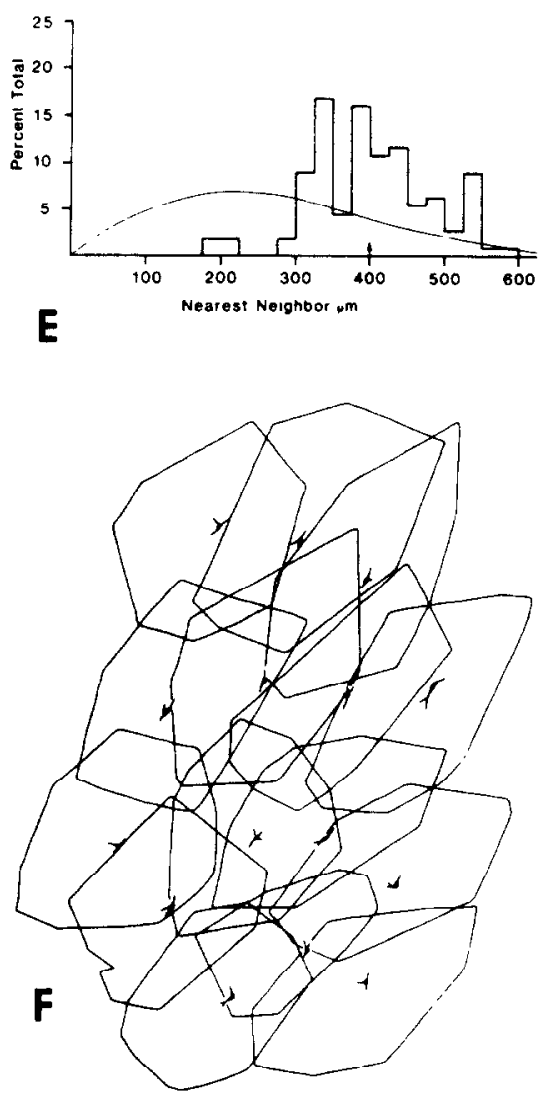

Fig. 2. (A, D) Camera-lucida drawings of the two retinae analysed in this study. Each dot represents the location of the soma of a Type 1.2 cell. A nearest neighbor analysis was performed for the cells enclosed within the dashed lines. Dorsal is up. Scale bar equals $2 \mathrm{~mm}$. (B, C) Nearest neighbor relative frequency histograms. The vertical arrowheads on the abscissae mark the averages [229 and $400 \mu \mathrm{m}$ in (B) and (C), respectively]. The smooth curves are distributions expected for random patterns with average densities as observed. (C, F) Somata and outlines of the dendritic fields of the cells enclosed by solid lines in the retinae shown in (A) and (D). Note the pronounced noncircularity of the dendritic fields (see Kock and Reuter, 1978b; Hitchcock and Easter, 1986). Scale bar equals $0.5 \mathrm{~mm}$.

\section{DISCUSSION}

It has been shown here that the Type 1.2 ganglion cell in the goldfish is nonrandomly distributed, and the dendritic fields of this cell type overlap such that every retinal point is covered by the dendritic field of at least one cell and often two. This is similar to what has been shown for ganglion cells in the cat (Wässle and Reimann, 1978; Wässle et al., 1981a, b, 1983). The novel result here is the direct demonstration that the dendritic coverage of the Type 1.2 cell 
is established at a time when the retina is small and ganglion cell density is high and is maintained as the retina grows by stretching [see also Kock and Reuter, 1978b; Kock, 1982b; and Macy and Easter (1981) for an electrophysiological analysis]. This constancy of the relative dendritic field organization is consistent with the hypothesis that the increase in the size of the dendritic arbors of ganglion cells within central retina of the goldfish is produced by the passive towing of the dendrites by the expanding retina (Hitchcock, 1985; Hitchcock and Easter, 1986).

The stretch of the retina and concomitant growth of the dendritic arbors in the goldfish is similar to that shown for the cat. By measuring the distance between adjacent alpha cells in retinal wholemounts, Mastronarde et al. (1984) showed that the retina of the neonatal cat grows by stretching. [No new ganglion cells are added postnatally (Johns et al., 1979).] Rusoff and Dubin (1978) showed that in the neonatal cat the dendritic fields of Golgi stained beta cells increase in area. Comparing the data of Rusoff and Dubin (1978) to their own, Mastronarde et al. (1984) concluded that passive towing of the beta cell's dendrites contributed to the dendritic growth of these cells, but by an amount that would result in dendritic fields smaller than those found in the adult. From this they concluded that in the cat the active growth of new dendrites must supplement the passive stretching of the beta cell's dendritic arbors. This is not the case for the mature Type 1.2 cells in the goldfish's central retina (see Results and Hitchcock and Easter, 1986). The dendritic growth of immature beta cells, however, is similar to the dendritic growth of the immature Type 1.2 cells that reside at the goldfish's retinal margin (Hitchcock and Easter, 1986). These cells expand their dendritic fields by both adding new dendrites and by the interstitial growth of their existing dendrites.

The data of Mastronarde et al. (1984) and Rusoff and Dubin (1978) and the data presented here (see also Hitchcock, 1985; Hitchcock and Easter, 1986) highlight the common mechanisms of ganglion cell development that these very different vertebrates share and suggests that other similarities in retinal development may exist as well (see Linden and Perry, 1982; Perry and Linden, 1982; Eysel et al., 1985).

Acknowledgements -1 thank Drs R. Bernhardt and S. S. Easter Jr for useful discussions, Ms M. Madouse for secretarial assistance, and D. Bay for photographic assistance. This work was supported by grants and EY-00168 to S. S. Easter and a postdoctoral fellowship. EY-005625 to P.F.H.

\section{REFERENCES}

Adams J. C. (1977) Technical considerations on the use of horseradish peroxidase as a neuronal marker. Neuroscience 2, 141-145.

Ali M. A. (1964) Stretching of retina during growth of salmon. Grow'th 28, 83-89.

Brecha N. C., Oyster C. W. and Takahashi E. S. (1984) Identification and characterization of tyrosine hydroxylase immunoreactive amacrine cells. Invest. Ophthal. visual Sci. 25, 66-70.

Easter S. S. Jr, Johns P. R. and Baumann L. R. (1977) Growth of the adult goldfish eye-I. Optics. Vision Res. 17, 469-477.

Eberhardt L. L. (1967) Some developments in "distance sampling". Biometrics 23, 207-216.

Eysel U. Th., Peichl L. and Wässle H. (1985) Dendritic plasticity in the early postnatal feline retina: quantitative characteristics and sensitive period. J. comp. Neurol. 242, 134-145.

Hitchcock P. F. (1985) Stretch of the retina contributes to the dendritic field area of ganglion cells in the retina of the black moor goldfish. Neurosci. Abstr. 11, 221.

Hitchcock P. F. and Easter S. S. Jr (1986) Retinal ganglion cells in goldfish: a qualitative classification into tour morphological types, and a quantitative study of the development of one of them. J. Neurosci. 6, 1037-1050.

Johns P. R. (1977) Growth of the adult goldfish eye. III. Source of the new retinal cells. J. comp. Neurol. 176, 343-358.

Johns P. R. and Easter S. S. Jr (1977) Growth of the adult goldfish eye. II. Increase in retinal cell number. J. comp. Neurol. 176, 331-342.

Johns P. R., Rusoff A. C. and Dubin M. Wm (1979) Postnatal neurogenesis in the kitten retina. J. comp. Neurol. 187, 545-556.

Kock J.-H. (1982) Neuronal addition and retinal expansion during growth of the crucian carp eye. J. comp. Neurol. 209, 264-274.

Kock J.-H. (1982) Dendritic tree structure and dendritic hypertrophy during growth of the crucian carp eye. $J$. comp. Neurol. 209, 275-286.

Kock J.-H. and Reuter T. (1978) Retinal ganglion cells in the crucian carp (Carassius carassius). I. Size and number of somata in eyes of different size. J. comp. Neurol. 179 , $535-548$.

Kock J.-H. and Reuter T. (1978) Retinal ganglion cells in the crucian carp (Carassius carassius). 11. Overlap, shape, and tangential orientation of dendritic trees. J. comp. Neurol. 179, 549-568.

Linden R. and Perry V. H. (1982) Ganglion cell death within the developing retina: $A$ regulatory role for retinal dendrites? Neuroscience 7, 2813-2827.

Lyall A. H. (1957) The growth of the trout retina. $Q$. $J l$ micros. Sci. 98, 101-110.

Mastronarde D. N., Thibeault M. A. and Dubin M. Wm (1984) Non-uniform postnatal growth of the cat retina. $J$. comp. Neurol. 228, 598-608.

Meyer R. L. (1978) Evidence from thymidine labelling for continuing growth of retina and tectum in juvenile goldfish. Expl Neurol. 59, 99-111. 
Müller H. (1952) Bau und Wachstum der Netzhaut des Guppy (Lebistes reticulatus). Zool. Jb., Abt. f. allg. Zool. u. Physiol., 63, 275-324.

Perry V. H. and Linden R. (1982) Evidence for dendritic competition in the developing retina. Nature, Lond. 297, 683-685.

Rusoff A. C. and Dubin M. Wm (1978) Kitten ganglion cells: Dendritic field size at 3 weeks of age and correlation with receptive field size. Invest. Ophthal. visual Sci. 17, 819-821.

Sandy J. and Blaxter J. H. S. (1980) A study of retinal development in larval herring and sole. J. Mar. Biol. Ass. U.K. 60, 59-71.

Sharma S. C. and Ungar F. (1980) Histogenesis of the goldfish retina. $J$. comp. Neurol. 191, 373-382.
Tauchi M. and Masland R. H. (1984) The shape and arrangement of the cholinergic neurons in the rabbit retina. Proc. $R$. Soc. B 223, 101-119.

Wässle H. and Riemann H. J. (1978) The mosaic of nerve cells in the mammalian retina. Proc. $R$. Soc. B 200, 441-461.

Wässle H., Peichl L. and Boycott B. B. (1981) Morphology and topography of on- and off-alpha cells in the cat retina. Proc. R. Soc. B 212, 157-175.

Wässle H., Peichl L. and Boycott B. B. (1981) Dendritic territories of cat retinal ganglion cells. Nature, Lond. 292, 344-345.

Wässle H., Peichl L. and Boycott B. B. (1983) A spatial analysis of on- and off-ganglion cells in the cat retina. Vision Res. 10, 1151-1160. 